|Araştırma Makalesi / Research Article|

\title{
İkinci Dil Eğitimi Alan veya İki Dilli ve İkinci Dil Eğitimi Almayan Tek Dilli Okul Öncesi Dönem Çocuklarının Alıcı ve ífade Edici Dil Gelişim Düzeylerinin Karşılaştırııması
}

\section{A Comparison of the Level of Development of Recipient Language and Expressive Language of Preschoolers Who Receive Second Language Education or Are Bilingual and Who Do Not Receive Second Language Education and Are Monolingual}

\section{Huriye HAMARAT ${ }^{1}$, Büşra ERGIN ${ }^{2}$}

\author{
Anahtar Kelimeler \\ 1.Alıcı dil gelişim \\ 2.ífade edici dil gelişimi \\ 3.İki dillilik \\ 4.Ikinci dil eğitimi \\ 5.Okul öncesi eğitim
}

Keywords
1.Bilingualism
2.Expressive language
development
3.Pre-school education
4.Receptive language
development
5.Second language
edecation

Başvuru Tarihi/Received

26.11.2019

Kabul Tarihi /Accepted

17.11.2020

\begin{abstract}
Öz
Bu araştırmanın temel amacı; okul öncesi eğitim kurumuna devam etmekte olan, 36-76 ay grubu, ikinci dil eğitimi almayan tek dilli okul öncesi dönem çocukları ile iki dilli veya ikinci dil eğitimi alan okul öncesi dönem çocuklarının alıcı ve ifade edici dil puan ortalamaları anlamlı olarak farklılaşmakta mıdır? sorusuna yanıt aramaktır. Ayrıca araştırmada sosyodemografik değişkenlerin dil puanları üzerindeki yordayıcı etkisini belirlemek istenmiştir. Bu çalışma, nicel bir araştırmadır, ilişkisel tarama modeli kullanılmıştır. Araştırma 2018-2019 eğitim- öğretim yılında okul öncesi eğitim kurumlarına devam etmekte olan 36-76 ay grubu 311 çocukla gerçekleştirilmiştir. Çocukların alıcı ve ifade edici dil gelişim düzeylerini belirlemek amacıyla, Türkçe Ifade Edici ve Alıc Dil Testi (TIFALDi), demografik özelliklerini belirlemek amacıyla da araştırmacı tarafından hazırlanan "Kişisel Bilgi Formu" kullanılmıştır. Kişisel bilgi formunda verilen demografik özellikleri ölçmek amacıyla yapılacak çözümlemeler için ise; tanımlayıcı istatistikler (yüzde, frekans, aritmetik ortalama ve standart sapma, mod, medyan değerleri) hesaplanarak tablo şeklinde verilmiştir. Verilere ilişkin frekans analizlerinin yanı sıra gruplar arası karşılaştırmalarda bağımsız gruplarda t testi kullanılmıştır. Ayrıca araştırmada, çocuğa ve anne-babaya ait sosyodemografik değişkenlerin, çocukların alıcı ve ifade edici dil puanlarını üzerindeki yordayıcı etkisini belirlemek amacıyla da hiyerarşik regresyon analizi yapılmıştır. Araştırma sonucunda ikinci dil eğitimi almayan tek dilli çocukların alıcı ve ifade edici dil puan ortalamaları iki dilli veya ikinci dil eğitimi alan çocuklarının alıcı ve ifade edici dil puan ortalamalarından istatiksel olarak anlamlı olmasa da yüksek çıkmıştır. Sosyodemografik değişkenlerden yaş, anne ve baba eğitim düzeyi, okula gelme süresi dil gelişimini pozitif ve anlamlı olarak açıklamakta, ikiz olma durumu ise negatif ve anlamlı olarak açıklamaktadır.

\section{Abstract}

The main purpose of thisresearch is to search for answers to the question "Do themean and receptive languagescores of the 36-76 monthgroup, preschool children who are not attending second language education and those who are bilingual or receiving second language education continue to be significantly different?" In addition, it was aimed to determine the predictive effect of sociodemographic variables on language scores. This study is a quantitative research, relational survey model is used. The research was carried out with 311 children in the $36-76$ month group attending preschool education institutions in 2018-2019 academic year. Turkish Expressive and Receptive language Test (TIFALDI) was used to determine the level of development of the receptive and expressive language, and the Personal Information Form prepared by the researcher was used to determine the demographic characteristics of the children. In order to measure the demographic characteristics given in the personal information form; Descriptive statistics (percentage, frequency, arithmetic mean and standard deviation, mode, median) were calculated and given in tabular form. In addition to frequency analysis of data, t-test was used in independent groups for comparisons between groups. In addition, hierarchical regression analysis was performed to determine the predictive effect of sociodemographic variables of children and parents on the scores of children's receptive and expressive language. As a result of the study, the mean scores of the monolingual children who did not receive second language education were higher than the mean scores of the children who are bilingual or receiving second language education, but not statistically significant. Among sociodemographic variables, age, education level of parents, duration of school attendance were positive and significant in terms of language development, and the state of being twins was negative and significant.
\end{abstract}

\footnotetext{
${ }^{1}$ Çorum Sungurlu Kaledere ilkokulu, Çorum, TÜRKiYE; https://orcid.org/0000-0003-3234-4740

2 Selçuk Üniversitesi, Eğitim Fakültesi, Temel Eğitim Bölümü, Konya, TÜRKiYE; https://orcid.org/0000-0001-5177-7096
} 


\section{INTRODUCTION}

Development begins before birth and rapidly progresses in the first six years of life, namely early childhood. In this first sixmonth period, the child's character and habit formation, acquisition of cultural values, physical, language, cognitive, emotionalsocial, moral and sexual development should be greatly nurtured by the adults around. Development theoreticians similarly emphasize the importance of an enriched early childhood to achieve a sound adult identity. Like other development areas, language development similarly plays a crucial significance in the child's life.

Oral and written language is an important communication tool in order that people learn and teach their feelings, ideas, experiences and cultural values (Sevinç, 2003; Samovar, Porter, \& McDaniel, 2009; Bonvillain, 2014). One of the functions of language is to represent ideas and another is to transfer these ideas. Transmitting ideas to another person and receiving their ideas establishes mutual communication. Communication is a process of exchanging information through a system of common symbols, signs and behaviour. It has existed since the beginning of life and has become a dynamic process with the evolution of mankind. All living beings transfer their messages in their unique way. It is only mankind that uses an extraordinary and fascinating way. While many animal species have sound and sound-based call systems, the transition from sounds to words and to oral expression is evolutionary. This behaviour which makes human beings superior to other living beings is also called "the ability to use language through speaking" or only "oral language" (Sperber \& Wilson, 1986; Topbaş, 2010; Enderby, Judge, Creer, \& John, 2013; Yule, 2017).

Language is the most powerful communication tool particular to human beings. Language is a system which performs social communication by uniting meaningful words, which are made up of symbols and signs within the scope of certain rules in order to ensure the transmission of intergenerational heritage by social amalgamation. In other words, it is a tool we use for learning about and sharing various thoughts, feelings, attitudes, beliefs, standards of judgement, for transferring information and cultural richness related to experiences gained by seeing or living, and for performing functions like inquiring, commanding and requesting (Temiz, 2002; Corballis, 2003; Çiyiltepe \& Türkbay, 2004; Gül Yazıcı, 2007; Çat Şahin, 2009; Kayılı, Koçyiğit \& Erbay, 2009).

There are different theories about the process of acquiring a language. According to Skinner, one of the pioneers of behavioral approach, language development is explained by operant conditioning. Skinner claims that people are not born with a language equipment but learn the language through imitation and modelling. Similarly, Bandura, who shaped social learning approach, asserts that language is learnt through imitation and observation. On the other hand, Chomsky holds the opinion that babies are born with a particular language acquisition ability but language development comes out through maturation. However, cognitive theoreticians explain language through Piaget, who emphasizes the importance of cognitive ability in language development, and Vygotsky, who emphasizes the importance of social interaction and environment.

When babies are born, they have the potential to acquire the language spoken in the environment in which they were born. Babies all over the world have the ability to make all the sounds from the moment they were born, and as time passes, they only repeat the sounds in the language spoken around them (Yazı cI and Ilter, 2008). Human beings begin to acquire the language around them from birth to express feelings and thoughts and communicate. The language develops in direct proportion with the development and socialization of the living space. As different languages are spoken by the environment acquired by the individual over time, the individual will acquire this language, which is different from the mother tongue, as the second language. With the globalization of the world, people involved in different nations have acquired a second language and the number of multilingual people has increased. This change has enabled different nations to live together and also provided a basis for discussing issues such as second language education and the age of starting this education.

Although the child shapes her/his language in the community where s/he lives, the main language is her/his mother tongue, the language $\mathrm{s} /$ he learned from the institution she lives in, namely from her/his family. It's the language s/he learned from her/his mother. When the language of another nation, a second language, is to be learned, the language, a tool for thinking, is shaped on the mother tongue and proceeds. The question "When should an individual start learning a second language?" is one of the most debated issues today, but the difficulties faced by individuals who have to use the second language have opened up a new field of research for researchers (Tulu, 2009).

Children, unlike adults, are easily able to fully learn the accent, rhythm and style of speaking. From the age of two, they are able use two languages without confusing them with each other. The children that learn a foreign language at an early age are able to have a better understanding of their mother tongue, and are aware of whether what they are saying is correct or wrong. Besides acquiring the pronunciation of the new language at a similar level to their mother tongue, the children receiving language education at an early age can also open doors for new cultures. Compared to monolingual children, they have a wider perspective and compared to their elders, they have an easier cultural interaction (Küçük, 2006).

Preschool period is a critical period in terms of development areas. Because most of the language development happens during this period, correct language education given in this period is going to turn into an advantage for their future years for the children that receive language education. Helping children and teens acquire the basic skills of a language and supporting them until they reach a satisfactory level is going to give them the opportunity to efficiently express themselves, their feelings and dreams to the community they live in and to the world (Senemoğlu, 2005).

The language is one of the chief ways of learning. Thus, children's both recipient and expressive language skills is an important predictor of their future academic achievements. A child that can listen and speak effectively does not only become successful in

|Kastamonu Eğitim Dergisi, 2020, Vol. 28, No. 6| 
their social relationships with others, but also excels in academic skills such as reading and writing. On the other hand, the children that do not develop the necessary language skills required by their age face social clash, reading disability and may encounter various problems at school.

Recipient language skills are the ones an individual uses to understand what the things around them mean. We use these skills when performing instructions and waiting our turn to speak during a conversation. At the same time, recipient language skills help us understand what others say (Tekin, 2007). Expressive language skill, however, is defined as transferring requests, feelings and ideas to other people using language. A baby's making sounds to get the toy it wants or saying the name of an object exemplifies expressive language skills. Expressive language skills involve the ability to produce various sounds, form words and sentences and use correct grammatical patterns (Uyanık, 2010).

When the literature is analyzed, it can be seen that some studies prove that the language development of monolingual children is ahead of those receiving language education and are bilingual. The studies that argue the opposite state that it is easier to acquire second language at an early age and that the children who receive second language education at an early age learn to think in the language patterns of that language and have a better pronunciation than those that learn that language later. This study aims at determining how being exposed to more than one language in the preschool period affects recipient and expressive language development by comparing bilingual or the children that receive second language education, with their peers that do not receive language education and are monolingual.

In accordance with the main purpose of the study, the answers of the following questions have been searched for:

1. Do the average recipient and expressive language marks of the children that attend a preschool education institution, are 36-76 month-old, do not receive second language education and are monolingual differentiate meaningfully from those preschoolers that are bilingual or receive second language education?

a. Do the sociodemographic variables related to the children themselves that attend a preschool education institution, are 36-76 month-old, do not receive second language education and are monolingual, and to their parents sufficiently explain the recipient language development levels?

b. Do the sociodemographic variables related to the children themselves that attend a preschool education institution, are 36-76 month-old, are bilingual or receive second language education, and to their parents sufficiently explain the recipient language development levels?

c. Do the sociodemographic variables related to the children themselves that attend a preschool education institution, are 36-76 month-old, do not receive second language education and are monolingual, and to their parents sufficiently explain the expressive language development levels?

d. Do the sociodemographic variables related to the children themselves that attend a preschool education institution, are 36-76 month-old, are bilingual or receive second language education, and to their parents sufficiently explain the expressive language development levels?

\section{METHOD}

This study is a quantitative research, and relational screening model which is one of the general survey models is used. Survey models are research approaches aiming to describe a past or present situation as it exists. In this model, individuals or events that are the subject of the research are observed and described in their own conditions without intervention. The relational screening model is used in studies that aim to determine the presence and / or the degree of co-change between two or more variables. In this kind of research, the variables to be searched for are collected separately and symbolized. However, this symbolization (valuation, measurement) should be done in a way that allows a relational analysis (Karataş, 2012). The information about population and sample, data collection tool, data collection process and data analysis will be givenin this section.

\section{Population and Sample}

The population of the study consists of 36-76 month-old children in kindergartens and nursery classes of primary schools of the Ministry of National Education located in Sungurlu District of Çorum Province and Manavgat District of Antalya Province in 2018-2019 academic year. The sample was determined by using criterion sampling method which is one of the purposive sampling methods. The criterion sampling is the study of all situations that meet a predetermined set of criteria. The criterion is established by the researcher or a list of previously prepared criteria can be used (Baltaci, 2018 citedin Marshall and Rossman, in 2014.).

The criteria for bilingual children or the children getting second language education wereattendance topreschool education for at least one educational period, being in the age range of 36-76 months, not having any disabilities. The criteriafor children gettingsecond language was attendance to language education for at least one educational period, and for bilingual children was exposure to both languages in the home environment. The criteria for monolingual children and the children not getting language educationwere attendance to pre-school education for at least one educational period, being between 36-76 months of age, and having no disabilities. 311 children who met these criteria were studied.

Considering the distribution of sociodemographic characteristics of 311 children in the study group, there were 162 girls, 149 boys; 26 children in 36-76 month group, 88 in 48-59 month group, 197 in 60-76 month group; 161 from Sungurlu District in Çorum 
Province, 150 from Manavgat District in Antalya Province; 178 with 0-1 years of schooling, 102 with 1-2 years of schooling and 31 with 2-3 years of schooling; 60 from lower socio-economic level, 179 from middle socio-economic level, 72 from upper socioeconomic level; 233 monolingual not getting second language education, 78 bilingual or receivingsecond language education; 237 going to public school, 74 going to private school; 11 with twins and 300 without twins.

\section{Data Collection Tools}

A personal information form was used in order to obtain the demographic information of the children included in the study group to collect the research data, and the Turkish Receptive and Expressive Language Test (TIFALDi) was used to determine the level of receptive and expressive language.

\section{Personal Information Form}

The form was prepared by the researcher to determine the demographic characteristics of the children participating in the study. The Personal Information Form includes questions about gender, age, duration of attendance to pre-school education, mother's education level, mother's profession, father's education level, father's profession, number of siblings, socio-economic level, bilingualism, second language education and duration of receiving second language education.

\section{Turkish Expressive and Receptive Language Test}

Turkish Expressive and Receptive Language Test (TIFALDI) consists of Turkish Expressive and Receptive Language Test (TIFALDI), the Receptive Language Vocabulary Sub Test and Expressive Language Sub Testdeveloped by a team led by Berument and Güven (2013).

\section{TIFALDI Receptive Language Vocabulary Subtest}

TIFALDI Receptive Language Vocabulary Sub-Test (Berument and Guven, 2013) consists of a total of 106 cards ranked from simple to difficult, evaluating the language understanding skills and vocabulary acquisition of children aged 2-12. Each card contains four images, one of which isfor the target word. When internal consistency coefficients were calculated separately for ages 3-7, it was found that Cronbach'salpha values ranged between 0.93 and 0.95 .

\section{TIFALDI Expressive Word Sub-Test}

TIFALDI Expressive Vocabulary Sub-Test (Berument and Guven, 2013) consists of 80 cards ranked from simple to difficult, used individually for children between the ages of 2-12 and evaluate the use of language with vocabulary. Each card has a single image that is expected to be answered as a single word. Expressive Language Sub-Test Internal consistency coefficients were calculated separately for ages 3-7 and Cronbach alpha values were found to be between 0.94 and 0.96 .

\section{Data Collection}

The Turkish Expressive and Receptive Language Test (TIFALDI) was administered by the researcher individuallyto 36-76 monthold children attending a preschool education institution in a room designed to give the child's attention to the test, and lasted between 25-40 minutes. The Personal Information Form and the "Parent Consent Form" were sent to the schools where the research was going to take place two weeks before the application of the test. The teachers of the children personally made the parents fill out the form.

\section{Data Analysis}

While analyzing the data, 39 children who did not fill out the Personal Information Form orhad incomplete forms were excluded from the study. The data obtained from the test applied to the children participating in the study were coded and uploaded to the computer and these data were analyzed by using SPSS 21.0 statistical package program.

In order to measure the demographic characteristics given in the personal information form, the values of descriptive statistics (percentage, frequency, arithmetic mean and standard deviation, mode, median) were calculated and given in tabular form. In addition to frequency analysis of data, t-test was used in independent groups for comparisons between groups. In addition, hierarchical regression analysis, which is one of the multiple linear regression analyzes, was applied in order to determine the predictive effect of sociodemographic variables of the children and parents on the receptive and expressive language scores of the children. Multiple regression analysis is a type of analysis for estimating the dependent variable based on two or more independent variables associated with the dependent variable. In the hierarchical method, the predictor variables are analyzed in the order that the researcher has determined before and each variable is evaluated in terms of its contribution to the variance related to the dependent variable (Özteke, 2015cited inBüyüköztürk, 2011). The level of significance was determined as 0.05.

Before analyzing the data, it was checked whether the data set was suitable for hierarchical regression analysis. Multiple regression analysis has some basic assumptions like other parameter analyzes (Özteke, 2015 cited inSeçer, 2013). These are sufficient sample size, multiple linear relations, singularity, extreme values and normality of distribution. Therefore, firstly, "Mahallanobis" distance values were calculated for obtaining and subtracting extreme values. Skewness and kurtosis values of the data were checked for 0.05 significance level. The data set was also examined in terms of multicollinearity assumption, 
correlation coefficients between independent variables were examined, VIF (VariancelnflationFactor) and Tolerance values were examined and it was observed that there were no multiple linearity problems between independent variables, and the analysis was performed.

\section{RESULTS}

Makalenin ana metninde yer alan paragrafların ilk satıı $0,5 \mathrm{~cm}$ girintili, paragraf öncesinde ve sonrasında 3er nk aralıklı ve tek satır aralıklı olarak yazılacaktır. Metin fontu(biçimi) “Calibri (Gövde)” ve puntosu (büyüklüğü) 10 olacaktır. Paragraf iki yana yaslı şekilde biçimlendirilecektir. Makalenin ana metninde yer alan paragrafların ilk satırı 0,5 cm girintili, paragraf öncesinde ve sonrasında 3er nk aralıklı ve tek satır aralıklı olarak yazılacaktır. Metin fontu(biçimi) “Calibri (Gövde)” ve puntosu (büyüklüğü) 10 olacaktır. Paragraf iki yana yaslı şekilde biçimlendirilecektir.

Table 1. Mean, median, minimum, maximum, ss values according toreceptive, expressive language raw score and age

\begin{tabular}{|c|c|c|c|c|c|c|}
\hline & $\mathrm{N}$ & Mean & Median & Minimum & Maximum & ss \\
\hline Chronological age (Month) & 311 & 61,19 & 63,00 & 36,00 & 76,00 & 8,78 \\
\hline $\begin{array}{l}\text { Receptive language raw } \\
\text { point }\end{array}$ & 311 & 63,38 & 66,00 & 6,00 & 106,00 & 19,38 \\
\hline $\begin{array}{l}\text { Expressive language raw } \\
\text { point }\end{array}$ & 311 & 47,29 & 49,00 & 2,00 & 74,00 & 14,54 \\
\hline $\begin{array}{l}\text { Receptive language } \\
\text { equivalent age (Month) }\end{array}$ & 311 & 77,90 & 77,00 & 27,00 & 144,00 & 19,49 \\
\hline $\begin{array}{l}\text { Expressive language } \\
\text { equivalent age (Month) }\end{array}$ & 311 & 80,69 & 76,00 & 25,00 & 144,00 & 25,68 \\
\hline
\end{tabular}

When Table 1 is examined, the chronological age arithmetic mean of children is 61.19 and the standard deviation is 8.78 . Chronological age extreme values are 36.76. When the raw scores are considered, the average arithmetic mean of the receptive language is 63.38 and the standard deviation is 19.38. Extreme values are 6-106. The arithmetic mean of the expressive language raw score is 47.29 and the standard deviation is 14.54. Extreme values are 6-106.

The arithmetic mean of the receptive language equivalent ages of the children participating in the study is 80.69 and the standard deviation is 25.68 . The receptive language equivalent age level of the children participating in the study is 25,144 . The arithmetic mean of the expressive language equivalent ages is 80.69 and the standard deviation is 25.68 . The extreme values of expressive language equivalent age level of the children participating in the study are 25, 144 . As can be seen in the table, Receptive and expressive equivalent ages of children are more than their chronological ages.

Table 2. Mean, median, minimum, maximum, ss, $t, p$ values of receptive and expressive language raw scores according to variable of being bilingual, getting second language education or being monolingual not getting second language education

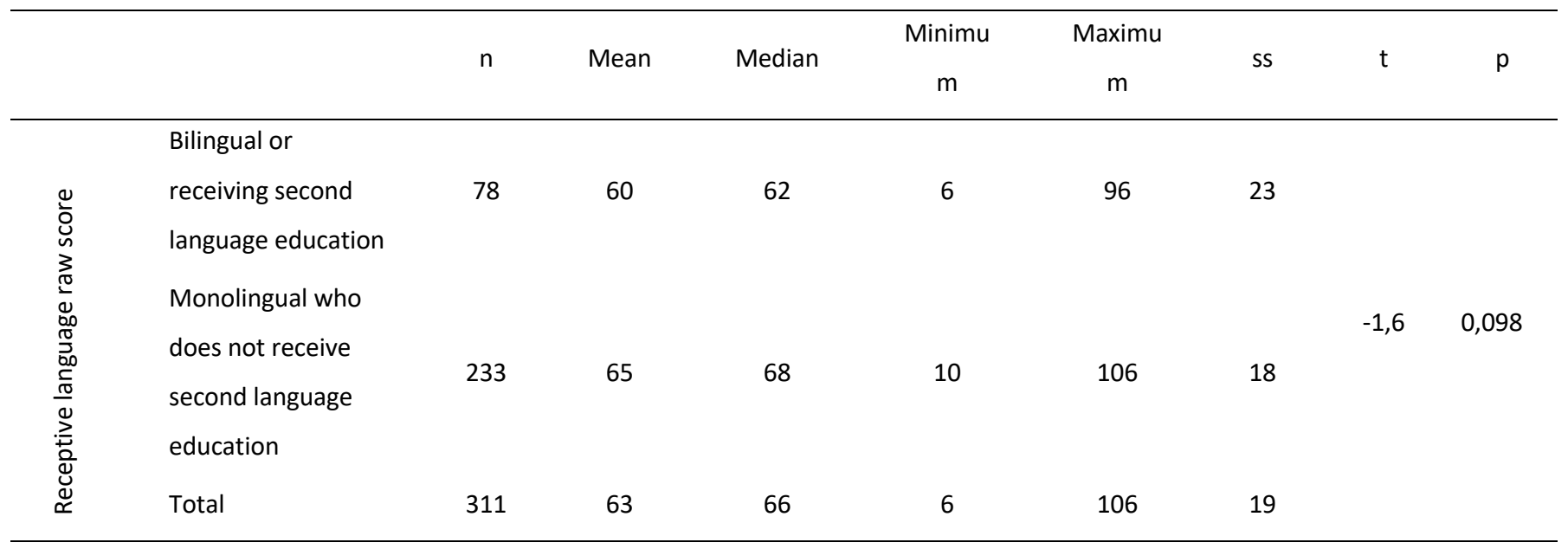




\begin{tabular}{|c|c|c|c|c|c|c|c|c|c|}
\hline & & $\mathrm{n}$ & Mean & Median & $\begin{array}{c}\text { Minimu } \\
\mathrm{m}\end{array}$ & $\begin{array}{c}\text { Maximu } \\
\text { m }\end{array}$ & ss & $\mathrm{t}$ & $\mathrm{p}$ \\
\hline \multirow{8}{*}{ 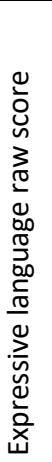 } & Bilingual or & & & & & & & \multirow{8}{*}{$-1,9$} & \multirow{8}{*}{0,058} \\
\hline & receiving second & 78 & 44 & 45 & 2 & 74 & 18 & & \\
\hline & language education & & & & & & & & \\
\hline & Monolingual who & & & & & & & & \\
\hline & does not receive & & & & & & & & \\
\hline & second language & 233 & 48 & 49 & 2 & 74 & 13 & & \\
\hline & education & & & & & & & & \\
\hline & Total & 311 & 47 & 49 & 2 & 74 & 15 & & \\
\hline
\end{tabular}

When the table is examined, TIFALDI (Turkish Expressive and Receptive Language Test) receptive language mean scores of 78 children who are bilingual or receiving second language education are 60, while TIFALDI (Turkish Expressive and Receptive Language Test) receptive language mean scores of 233 monolingual children who do not have second language education are 65. p> 0.05 was found when the difference between TIFALDI (Turkish Expressive and Receptive Language Test) receptive language mean scores were checked by t-test. Although it is not statistically significant, it is seen that mean scores of the children who are monolingual (non-bilingual) and not having second language education are higher.

TIFALDI (Turkish Expressive and Receptive Language Test) expressive language mean scores of 78 bilingual children or the children receiving second language education are 44 and TIFALDI (Turkish Expressive and Receptive Language Test) expressive language mean scores of 233 monolingual children who do not have second language education are 48 . $p>0.05$ was found when the difference between TIFALDI (Turkish Expressive and Receptive Language Test) expressive language mean scores were checked by t-test. Although it is not statistically significant, it is seen that the mean scores of the monolingual children who do not receive second language education are higher.

Table 3. Results of the Hierarchical Regression Analysis onPredictingReceptive Language Scores of Monolingual Children not having Second Language Education

Predicted Variable; Receptive Language Score for Monolingual children not receiving Second Language Education

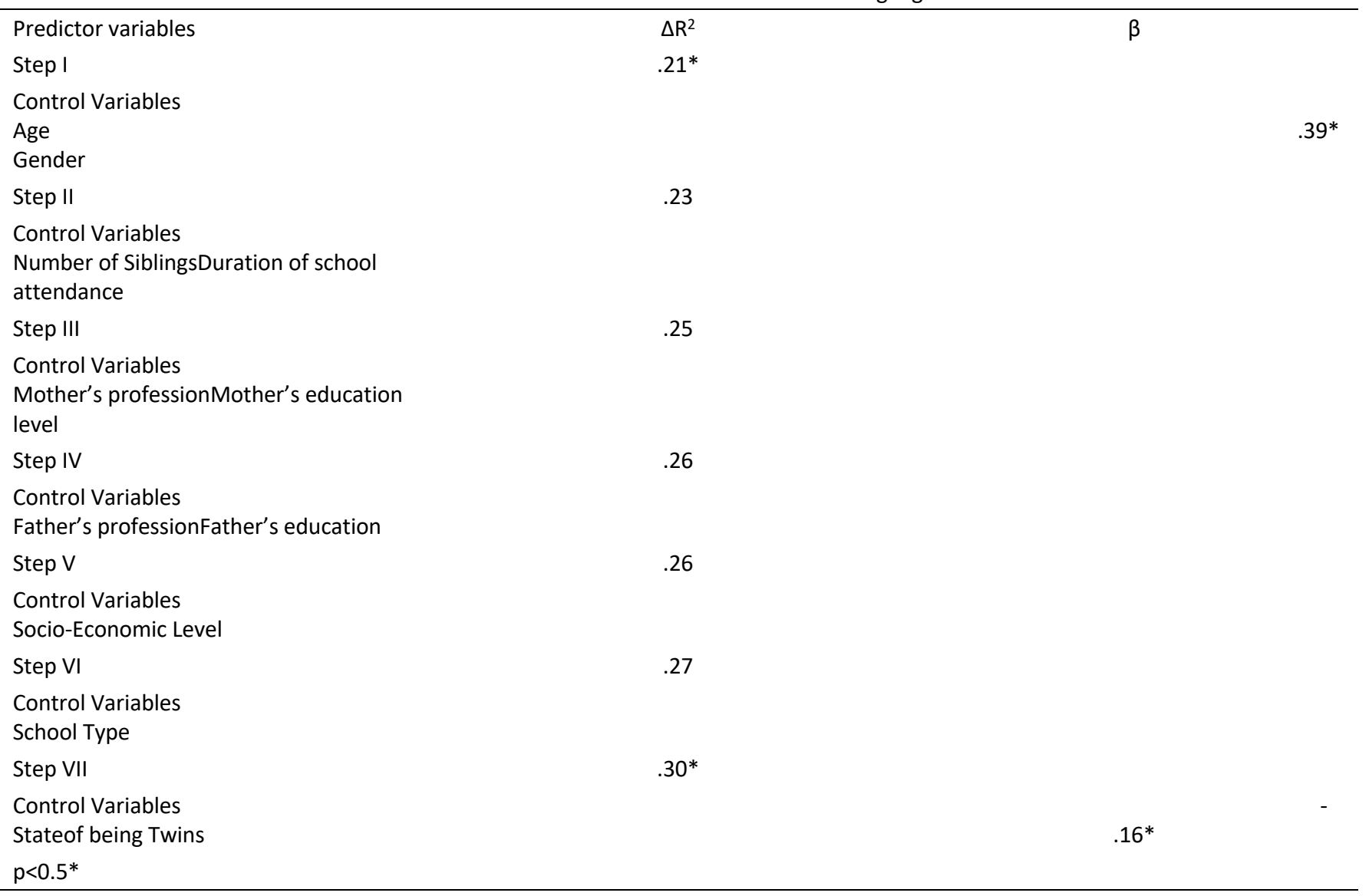


In Table 3, in the hierarchical regression analysis in which the receptive language was examined in terms of demographic variables that areindependent variables, it was observed that age and gender variables that entered the model in Step 1 had a significant contribution to the model $(R 2=.21, p<.05)$. Age and gender variables contributed $21 \%$ to the model. While the gender variable does not have an original contribution to the model, the age variable has an original contribution to the model ( $\beta=.39, p$ $<.05)$. As the age of the monolingual child who does not receive a second language education increases, so does the receptive language score. It was observed that the number of siblings and duration of school attendance entering the model in step 2, mother's profession andmother's education levelentering in step 3,father's professionand father's education level entering in step 4 , socioeconomic level entering in step 5 and school type entering in step 6 were not significant in the model. The state of being twins entering the model in the 7 th and last step has a significant contribution to the model. $(R 2=.30, p<.05)$. The state of being twins variable has a $30 \%$ contribution to the model. The state of being twins variable hasan original contribution to the model( $\beta$ $=-.16, p<.05)$. As the state of being twins is observed in the monolingual child who does not receive a second language education, the receptive language score decreases.

Table 4. Results of the hierarchical regression analysis onpredicting receptive language scores of bilingual children or the children receiving second language education

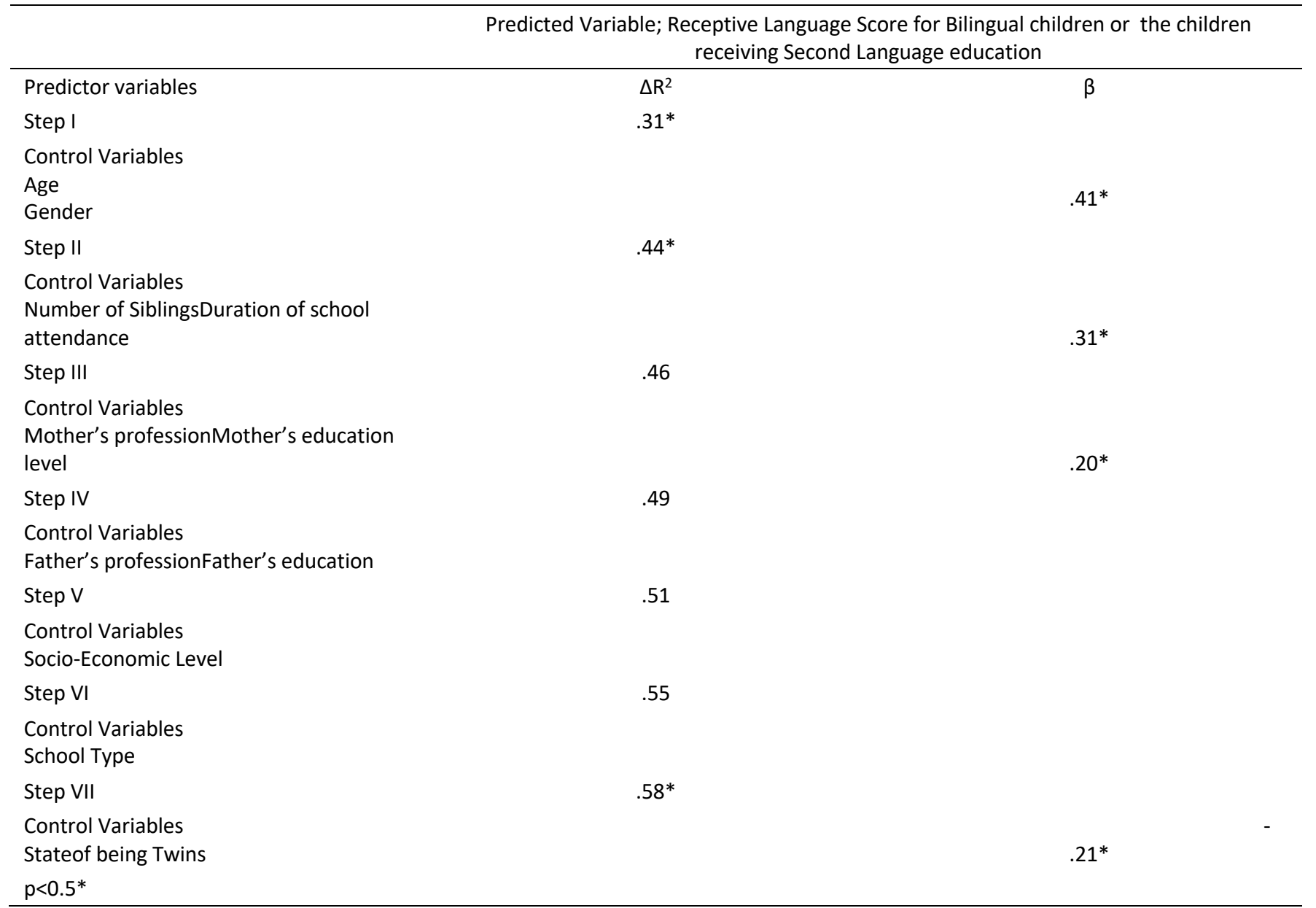

In Table 4, in the hierarchical regression analysis in which the receptive language was examined in terms of demographic variables, independent variables, it was observed that age and sex variables entering the model in Step 1 had a significant contribution to the model ( $R 2=.31, p<.05)$. Age and gender variables contributed $31 \%$ to the model. While the gender variable does not have an original contribution to the model, the age variable has an original contribution to the model $(\beta=.41, p<.05)$. As the age of the bilingual child or the child receiving a second language education increases, so does the receptive language score. It was observed that the number of siblings and duration of school attendance entering the model in step 2 had a significant contribution to the model ( $R 2=.44, p<.05)$. The variables of the number of siblings and duration of school attendance made $44 \%$ contribution to the model. While the number of siblings variable does not have an original contribution to the model, duration of school attendance variable has an original contribution to the model $(\beta=.31, p<.05)$. As the duration of school attendance of a bilingual child or the child receiving second language education increases, so does the receptive languagescore. It was observed that the variables of mother's profession and mother's education level, which entered the model in step 3, had a significant contribution to the model ( $R 2=.46, p<.05)$. The variables of mother's profession and mother's education level made a $46 \%$ contribution to the model. While there is no specific contribution of the mother's profession variable to the model, the mother's education level variable has an original contribution to the model $(\beta=.20, p<.05)$. It is seen that the variables of father's profession, father's education level enteringthe model in step 4, socioeconomic level enteringin step 5 and school type enteringin 
step 6 were not significant in the model. The state of being twins variable entering the model in the 7th and last step has a significant contribution to the model. ( $R 2=.58, p<.05)$. The state of being twins has a $58 \%$ contribution to the model. The state of being twins variable has an original contribution to the model $(\beta=-.21, p<.05)$. As the state of being twins increases in bilingual children or the children receiving second language education, the receptive language score decreases.

Table 5. Results of the hierarchical regression analysis onpredicting the expressive language scores of monolingual children who do not have second language education

Predicted Variable; Expressive Language Score for Monolingual children not receiving Second Language Education

\begin{tabular}{|c|c|c|}
\hline Predictor variables & $\Delta R^{2}$ & $\beta$ \\
\hline Step I & $.14^{*}$ & \\
\hline \multicolumn{3}{|l|}{ Control Variables } \\
\hline $\begin{array}{l}\text { Age } \\
\text { Gender }\end{array}$ & & $.39 *$ \\
\hline Step II & .17 & \\
\hline \multicolumn{3}{|l|}{$\begin{array}{l}\text { Control Variables } \\
\text { Number of SiblingsDuration of school } \\
\text { attendance }\end{array}$} \\
\hline Step III & .20 & \\
\hline \multicolumn{3}{|l|}{$\begin{array}{l}\text { Control Variables } \\
\text { Mother's professionMother's education } \\
\text { level }\end{array}$} \\
\hline Step IV & .22 & \\
\hline \multicolumn{3}{|l|}{ Control Variables } \\
\hline Father's professionFather's education & & $.15^{*}$ \\
\hline Step V & .22 & \\
\hline \multicolumn{3}{|l|}{$\begin{array}{l}\text { Control Variables } \\
\text { Socio-Economic Level }\end{array}$} \\
\hline Step VI & .22 & \\
\hline \multicolumn{3}{|l|}{$\begin{array}{l}\text { Control Variables } \\
\text { School Type }\end{array}$} \\
\hline Step VII & .23 & \\
\hline \multicolumn{3}{|l|}{$\begin{array}{l}\text { Control Variables } \\
\text { Stateof being Twins }\end{array}$} \\
\hline $\mathrm{p}<0.5^{*}$ & & \\
\hline
\end{tabular}

In Table 5, in the hierarchical regression analysis in which the expressive language was examined in terms of demographic variables that are independent variables, it was observed that age and gender variables that entered the model in Step 1 had a significant contribution to the model $(\mathrm{R} 2=.14, \mathrm{p}<.05)$. Age and gender variables contributed $14 \%$ to the model. While the gender variable does not have an original contribution to the model, the age variable has an original contribution to the model $(\beta=.39$, $\mathrm{p}<.05)$. As the age of the monolingual child who does not receive a second language education increases, so does the expressive language score. It was observed that the number of siblings and duration of school attendance entering the model in step 2 , mother's profession and mother education entering in step 3were not significant in the model. Father's profession and father's education level variables entering the model in step 4contributed $22 \%$ to the model. While father's professionvariable has no specific contribution to the model, father's education level variable has an original contributionto the model $(\beta=.15, p<05)$. As the father's education level of the monolingual child who does not receive second language education increases, so does the expressive language score. The socioeconomic level entering into the model in step 5, the school type entering in step 6, and the state of being twinsentering in the 7 th and last step were not significant in the model.

Table 6. Results of the hierarchical regression analysis on predicting the expressive language scores of bilingual children or the children receiving second language education

Predicted Variable; Expressive Language Score for Bilingual children or the children receiving Second Language Education

\begin{tabular}{lll}
\hline Predictor variables & $\Delta \mathrm{R}^{2}$ & $\beta$ \\
Step I & $.19^{*}$ & \\
Control Variables & & $.30^{*}$ \\
Age & & \\
Gender & $.31^{*}$ & \\
Step II & & \\
\hline
\end{tabular}


Control Variables

Number of SiblingsDuration of school

attendance

Step III

Control Variables

Mother's professionMother's education

level

Step IV

Control Variables

Father's professionFather's education

Step V

Control Variables

Socio-Economic Level

Step VI

Control Variables

School Type

Step VII

Control Variables

Stateof being Twins

$p<0.5$

In Table 6, in the hierarchical regression analysis, where the expressive language was examined in terms of demographic variables, independent variables, it was observed that age and gender variables that entered the model in step 1 had a significant contribution to the model $(\mathrm{R} 2=.19, \mathrm{p}<.05)$. Age and gender variables contributed $19 \%$ to the model. While the gender variable does not have an original contribution to the model, the age variable has an original contribution to the model $(\beta=.30, p<.05)$. As the age of the bilingual child or the child receiving a second language education increases, so does the expressive language score. It was observed that the variablesof the number of siblings and duration of school attendancethat entered into the model in step 2 had a significant contribution to the model $(R 2=.31, p<.05)$. The variables of the number of siblings and duration of school attendance contributed $31 \%$ to the model. While the number of siblings variable does not have an original contribution to the model, duration of school attendance variable has an original contribution to the model $(\beta=.32, p<.05)$. As the duration of school attendance of a bilingual child or the child who receives second language education increases, so does the expressive language score. It was observed that mother's profession and mother's education level variables that entered in step 3 had a significant contribution to the model ( $R 2=.36, p>.05)$. The variables of mother's profession and mother's education level contributed $36 \%$ to the model. While there is no specific contribution of the mother's profession variable to the model, the mother's education level variable has an original contribution to the model $(\beta=.26, p<0.5)$. As the mother's education level of bilingual child or the child receiving second language increases, so does the expressive language score. It was seen that father's education level andfather's professionentering in step 4 and socioeconomic level variable entering in step 5 were not significant in the model. The school type entering into the model in step 6 was found to have a significant contribution to the model $(\mathrm{R} 2=$ $.47, \mathrm{p}<.05)$. The school type variable has a $47 \%$ contribution to the model. The school type variable has an original contribution to the model $(\beta=.26, p<05)$. The expressive language score also increases when the school type ofbilingual child or the child receivingsecond language education is changed from a public school to a private school. The state of being twins variable that entered in the 7th and last step has a significant contribution of to the model ( $R 2=.58, p<.05)$. The state of being twins variable hasan original contribution to the model $(\beta=-.40, p<.05)$. Asthe state of being twins increases in bilingual children or children receiving second language education, the expressive language score decreases.

\section{DISCUSSION}

The main purpose of this study is to examine the differentiation of the receptive and expressive language development of monolingual preschool children who do not receive second language education and preschool children who are bilingual or receiving second language education. The effect of various sociodemographic variables (gender, age, duration of pre-school attendance, mother's education level, father's education level, mother's profession, father's profession, number of siblings, socioeconomic level, school type, the state of being twins) on children's receptive and expressive language scores was investigated.

Regarding the comparison of the expressive and receptive languagemean scores of the 36-76 month group, monolingualpreschool children not receiving second language education and the preschool children who are bilingual or receiving second language education; 
According to the results of the study, the mean scores of the receptive language and the expressive language are in favor of monolingual children who do not receive second language education. There are various studies comparing the development of receptive and expressive language in monolingual children and bilingual children or the childrenreceiving second language education (Skutnabb, 1981; Yazıcı, 2003; Bekir, 2004; Akdoğan, 2005; Baker, 2004; Caprez-Krompak, 2007; Tulu, 2009; Ozer, 2013; Gain, 2017). For example, Yazıcı (2003) investigated the mother tongue development levels and mother tongue acquisition problems of immigrant children living abroad. 120 children aged 5-6 including 30 in Norway, 30 in Austria, 30 in Germany, 30 in Turkey participated in the study. According to study results, the language level of Turkish children living abroad was found to be too low compared to their peers in Turkey.

Onpredicting the expressive and receptive language development levels by the socio-demographic variablesof the 36-76 month old monolingual preschool children who do not receive second language education and the preschool children who arebilingual or receivingsecond language education and their parents;

According to the findings of the study, sociodemographic variables of monolingual preschool children who do not receive second language education such as gender, number of siblings, duration of school attendance, mother's profession, mother's education level, father's profession, father's education level, socioeconomic level, school type do not significantly explain the development of the receptive language, while age explains positively and significantly, the state of being twins explains negatively and significantly. There are various studies that reveal the relationship between age and receptive language development (Binbaşıoğlu, 1990; Aydoğan and Koçak, 2003; Yıldırım, 2008; Tulu, 2009; Kılıç, 2014). For example, Kılıç (2014) studied with first graders and found that the language skills of 60-66-month-old children were behind the language skills of 66-72-month-old children, and that the language skills of 66-72-month-old children were behind the 72+-month-old children. The results of various studies are similar to the findings of the research.

The sociodemographic variables of preschool children who are bilingual or receivingsecond language education such as gender, number of siblings, mother's profession, father's profession, father's education level, socioeconomic level, school type do not significantly explain receptive language development, while the age, duration of school attendance, mother's education level explains positively and significantly, the state of being twinsexplains negatively and significantly. There are various studies that reveal the relationship between the development of the receptive language and the duration of school attendance (Yazıcl, 1999; Taner and Başal, 2005; Dereli, Koçak and Tepeli, 2005; Damarlı-Ocak, 2007; Tulu, 2009).

Dereli, Koçak and Tepeli (2005) conducted a study to examine the language levels of children attending and not attending preschool education institutions. 180 children aged 5-6 attending and not attending kindergarten participated in the study as experimental and control groups. The language development levels of the children were measured by the "Dictionary and Language Test". As a result of the study, it was found that average expressive language scores of the children between the ages of 5-6 attending preschool education institution were significantly higher than the scores of those not attending a preschool education institution at the same age range. The results of various studies are similar to the findings of the research.

The results of the study in which Öztürk (1995) used Peabody Picture Vocabulary Test to measure the receptive language levels and the Glossary Language test to measure expressive language levelsof 5-6 age group first-grade studentsand observed that children's levels of receptive and expressive language development increased in parallel with increasing educational level are similar to the findings of the study.

According to the findings of the study, sociodemographic variables of monolingual preschool children who do not receive second language education such as gender, number of siblings, duration of school attendance, mother's profession, mother's education level, father's profession, socioeconomic level, school typedo not explain expressive language development significantly, while age and father's education level explainpositively and significantly. There are several studies that reveal the relationship between expressive language development and father's education level (Davis-Kean, 2005; Yıldırım, 2008; Tulu, 2009; Can-Yaşar and Aral, 2011). For example, Yıldırım (2008) examined the language development of children in his study and found that the increase in the education level of the father contributed to the language development of children and he concluded that fathers are now active in raising children. The results of various studies are similar to the findings of the research.

According to the findings of the study, the sociodemographic variables of preschool bilingual children or the children receiving second language education, such as gender, number of siblings, mother's profession, father's profession, father's education level, socioeconomic level do not explain the expressive language development significantly, while age, duration of school attendance, mother's education level, school type explain positively and significantly, the state of being twinsexplains negatively and significantly. The reason for the increase in expressive language development scores when transferred from a public school to a private school can be shown as the education program used in the private school and the children of the families in the upper socioeconomic level. There are various studies that reveal the relationship between expressive language development and socioeconomic level (Temel, 2000; Damarlı-Ocak, 2007; Yıldırım, 2008; Tulu, 2009; Kılıç, 2014; Kazancı, 2017).

In his study, Kazancı (2017) examined the receptive and expressive language development of 355 primary school first grade students in Van province and measured the expressive and receptive language development of children with the Turkish Expressive and Receptive language Test (TIFALDI). When the relationship between the scores and socioeconomic level was examined, the result was found to be in favor of children with high socioeconomic level. 


\section{CONCLUSION AND SUGGESTIONS}

The main purpose of this research is to search for answers to the question"Do the mean scores of receptive and expressive language of the 36-76 month-old, monolingual preschool children who do not receive second language education and preschool children who are bilingual or receiving second language education differ significantly? The following results related to the findings obtained in line with the main and sub-objectives of the study are given.

According to the results of the study, the receptive language mean scores of the monolingual preschool children who do not receive second language education were higher than the mean scores of the pre-school childrenwho are bilingual or receiving second language, but not statistically significant.

The expressive language scores of monolingual preschool children who do not receive second language education were higher than the expressive language scores of preschool children who are bilingual or receiving second language education, but not statistically significant.

According to the results of the study, the sociodemographic variables of the monolingual preschool children who do not receive second language education such as gender, number of siblings, duration of school attendance, mother'sprofession, mother's education level, father'sprofession, father's education level, socioeconomic level, and school type do not explain the development of receptive language significantly, while age explains positively and significantly and the state of being twins explains negatively and significantly.

The sociodemographic variables of the preschool children who are bilingual or not receiving second language education such as gender, number of siblings, mother's profession, father's profession, socioeconomic level, and school type do not explain the development of receptive language significantly, while age, duration of school attendance, mother's education level explain positively and significantly, and the state of being twinsexplain negatively and significantly.

According to findings of the study, the sociodemographic variables of the monolingual preschool children who do not receive second language education and of their parents such as gender, number of siblings, duration of school attendance, mother's profession, mother's education level, father's profession, socioeconomic level, and school type do not explain the development of expressive language significantly, while age and father's education level explain positively and significantly.

According to findings of the study, the sociodemographic variables of the preschool children who are bilingual or not receiving second language education and of their parents such as gender, number of siblings, mother's profession, father's profession, father's education level, socioeconomic level do not explain the development of expressive language significantly, while age, duration of school attendance, mother's educationlevel and school type explain positively and significantly, and the state of being twins explain negatively and significantly.

The following suggestions are presented in the light of the data obtained from the research.

The main limitation of this study is that it consists of students attending nursery classes within primary schoolsand independent kindergartens in Çorum and Antalya. Therefore, the development of receptive and expressive language can be studied by considering larger, different samples and different variables.

By preparing a training program to support the development of receptive and expressive language, the effect of the supportive training program taken by bilingual children or the children receiving second language education on the development of receptive and expressive language can be studied.

In this study, bilingual children or the children receiving second language education were considered as a group. The comparison of receptive and expressive language development levels of bilingual children and the children who do not receive second language education can be studied.

In this study, bilingual children or children receiving second language education were considered as a group. It is possible to compare the level of receptive and expressive language development of children who receive second language education and those who do not receive second language education.

TIFALDI test (Turkish Expressive and Receptive language Test) measures the Turkish language development of children. By conducting a research that measures the second language development of children, the relationship between the development of the two languages can be examined.

New assessment tools can be developed to measure the language development of bilingual children or the children receiving second language education. 


\section{REFERENCES}

Aydoğan, Y. \& Koçak, N. (2003). Okul öncesi çocukların dil gelişimlerine etki eden faktörlerin incelenmesi. Milli Eğitim Dergisi, 159. https://dhgm.meb.gov.tr/yayimlar/dergiler/Milli_Egitim_Dergisi/159/aydogan-kocak.html 12.11.2018 tarihinde erişildi.

Baker, C. (2004). Foundations of bilingual education and bilingualism. Clevedon: Multilingual Matters Ltd.

Baltacı, A. (2018). Nitel araştırmalarda örnekleme yöntemleri ve örnek hacmi sorunsalı üzerine kavramsal bir inceleme. Bitlis Eren Üniversitesi, Sosyal Bilimler Enstitüsü Dergisi, 7(1), 231-274.

Bekir, H. (2004). Almanya'da okul öncesi eğitim kurumlarına devam eden 5-6 yaş grubu Türk çocuklarına uygulanan dil eğitim programının dil gelişimine etkisi. (Yayımlanmamış Doktora Tezi). Gazi Üniversitesi, Sosyal Bilimler Enstitüsü, Ankara.

Berument, S. K. and Güven, A. G. (2013). Türkçe İfade Edici ve Alıcı Dil (TiFALDi) Testi: I. Alıcı Dil Kelime Alt Testi Standardizasyon ve Güvenilirlik Geçerlik Çalışması. Türk Psikiyatri Dergisi, 24(3),192-201.

Binbaşıoğlu, C.(1990). Gelişim psikolojisi(5.Baskı). Ankara: Kadıoğlu Matbaası.

Bonvillain, N. (2014). Language, culture, and communication: The meaning of messages. UK: Pearson Publishing.

Can-Yaşar, M. \& Aral, N. (2011). Altı Yaş Çocuklarının Yaratıcı Düşünme Becerilerine Sosyo-Ekonomik Düzey ve Anne Baba Öğrenim Düzeyinin Etkisinin İncelenmesi. Kuramsal Eğitimbilim Dergisi, 4(1), 137-145.

Caprez-Krompak, E. (2007). Die bedeutung der erstsprache im integrationsprozess. http://www.terra-cognita.ch/10/caprez.pdf 03.04.2019tarihinde erişildi.

Corballis, M.C. (2003). İşaretten konuşmaya/Dilin kökeni ve gelişimi. İstanbul: Kitap Yayınevi.

Çat Şahin, A. (2009). Okul öncesi eğitim kurumuna devam eden 5-6 yaş grubu çocukların dil gelişimi ile annelerin okuma ilgi ve alışkanlıkları arasındaki ilişkinin çeşitli değişkenler açısından incelenmesi. Yayımlanmamış yüksek lisans tezi. Abant İzzet Baysal Üniversitesi, Sosyal Bilimler Enstitüsü, Bolu.

Çiyiltepe, M., \& Türkbay, T. (2004). Konuşmanın bileşenleri ve konuşma gecikmesi olan çocukların değerlendirilmesi: Gözden geçirme. Çocuk ve Gençlik Ruh Sağlığı Dergisi, 11(2), 90.

Damarlı-Ocak, S. (2007).ilköğretim birinci sınıf öğrencilerinin dil gelişim düzeyleri ile okuma-yazma başarısı arasındaki ilişki.(Yayımlanmamış yüksek lisans tezi).Marmara Üniversitesi, Eğitim Bilimleri Enstitüsü, İstanbul.

Davis-Kean, P. E. (2005). The influence of parent education and family income on child achievement: the indirect role of parental expectations and the home environment. Journal of Family Psychology, 19(2),294.

Dereli, E., Koçak, N. \& Tepeli, K. (2005, Eylül). Okulöncesi eğitim kurumuna devam eden ve etmeyen çocukların ifade edici dil düzeylerinin incelenmesi. XIV. Ulusal Eğitim Bilimleri Kongresinde sunulmuş sözlü bildiri, Pamukkale Üniversitesi, Denizli.

Enderby, P., Judge, S., Creer, S., \& John, A. (2013). Examining the need for and provision of AAC methods in the UK. Advances in Clinical Neuroscience \& Rehabilitation, $20-23 . \quad 13, \quad$ Erişim adresi: https://www.researchgate.net/publication/316182482_Examining_the_Need_for_and_Provision_of_AAC_Methods_in_the_UK

Gül Yazıcı, Z. (2007). Birinci ve ikinci dili Türkçe olan iki dilli çocukların Türkçeyi kazanmalarına dil merkezli okul öncesi eğitim programlarının etkisi. Yayımlanmamış doktora tezi. Gazi Üniversitesi, Eğitim Bilimleri Enstitüsü, Ankara.

Karataş, S.(2012).Bilimsel araştırma yöntemleri

http://aves.akdeniz.edu.tr/ImageOfByte.aspx?Resim=8\&SSNO=13\&USER=318012.09.2019 tarihinde erişildi.

Kayılı, G., Koçyiğit, S., \& Erbay, F. (2009). Montessori yönteminin beş-altı yaş çocuklarının alıcı dil gelişimine etkisinin incelenmesi. Selçuk Üniversitesi Türkiyat Araştırmaları Dergisi, 26, 347-355.

Kazancı, E.E. (2017). Illkokul birinci sınıf öğrencilerinin Türkçe ifade edici ve alıcı dil gelişimlerinin incelenmesi. (Yayımlanmamış yüksek lisans tezi). Yüzüncü Yıl Üniversitesi, Eğitim Bilimleri Enstitüsü, Van.

Kılıç, S. (2014).illkokul birinci sınıfa devam eden 60-66-72 aylık öğrencilerin dil becerilerinin incelenmesi.(Yayımlanmamış yüksek lisans tezi). Marmara Üniversitesi, Eğitim Bilimleri Enstitüsü, İstanbul.

Küçük, M. (2006). Okul öncesinde yabancı dil eğitimi konusunda eğitimcilerin ve ailelerin görüşleri.(Yayımlanmamış yüksek lisans tezi). Çukurova Üniversitesi, Sosyal Bilimler Enstitüsü, Adana.

Özer, H. (2013).Okul öncesi eğitim kurumuna devam eden 48-60 ay ve 61-72 ay grubu çocukların ana dil gelişimleri ile ikinci dil öğrenmeleri arasındaki ilişkinin incelenmesi. (Yayımlanmamış yüksek lisans tezi). Çukurova Üniversitesi, Sosyal Bilimler Enstitüsü, Adana.

Özteke, H.i..(2015). Bağlanma, eş seçiminde sınırlandırıcı inançlar ve beden imgesi baş etme stratejileri romantik ilişkilerde mükemmeliyetçiliği yordaması.(Yayımlanmamış doktora tezi). Necmettin Erbakan Üniversitesi, Eğitim Bilimleri Enstitüsü, Konya.

Öztürk, H. (1995). Okul öncesi eğitim kurumlarına devam eden ve etmeyen birinci sınıf çocukların alıcı ve ifade edici dil düzeyleri. (Yayımlanmamış yüksek lisans tezi). Gazi Üniversitesi, Sosyal Bilimler Enstitüsü, Ankara.

Samovar, A., Porter, E., \& McDaniel, R. (2009). Communication between cultures. Boston: Wadsworth.

Senemoğlu, N. (2005). Gelişim öğrenme ve öğretim kuramdan uygulamaya. Ankara: Gazi Kitabevi.

Sevinç, M. (2003). Dil gelişimi ve ilköğretime hazırlık. M.Sevinç (Edt.). Erken çocuklukta gelişim ve eğitimde yeni yaklaşımlar içinde (s.169-183). İstanbul: Morpa Yayınevi.

Sevinç, M. (2003). Okul öncesi dönemde okuma yazma kavramlarının gelişimi. M.Sevinç (Edt.). Erken çocuklukta gelişim ve eğitimde yeni yaklaşımlar içinde (s.177 -183). İstanbul: Morpa Yayınevi. 
Skutnabb, K. (1981). Çok dilli konular.https://www.researchgate.net/publication/268279133_SkutnabbKangas_Tove_2007_19811984_Bilingualism_or_not_the_education_of_minorities_Clevedon_Avon_Multilingual_Matters_378_p_revis ed_Southeast_Asian_version_with_an_Introduction_by_Ajit_Mohanty_New_Del 08.03.2019 tarihinde erişildi.

Sperber, D., \& Wilson, D. (1986). Relevance: Communication and cognition. Cambridge: Harvard University Press.

Taner, M. \& Başal, H. (2005). Farklı sosyoekonomik düzeylerde okulöncesi eğitimi alan ve almayan ilköğretim birinci sınıf öğrencilerinin dil gelişimlerinin cinsiyete göre karşılaştırılması, Uludağ Üniversitesi Eğitim Fakültesi Dergisi,17(2), 395-420.

Tekin, E. (2007). Küçük adımlar gelişimsel geriliği olan çocuklara yönelik erken eğitim programı alıcı dil becerileri. İstanbul: Daktylos Yayınevi.

Temel, Z. F. (2000). Erken çocukluk döneminde dilgelişimi: sosyo-ekonomik düzey ve cinsiyet ilişkisi. GÜGEF Dergisi, 20(2), 39-53.

Temiz, G. (2002). Okulöncesi eğitimin çocuğun gelişimine olan etkisi. (Yayımlanmamış yüksek lisans tezi). Selçuk Üniversitesi, Sosyal Bilimler Enstitüsü, Konya.

Topbaş, S. (2010). Dil ve kavram gelişimi. Ankara: Kök Yayıncılık.

Tulu, Y. (2009). Ana dili Türkçe olan ve ana dili Türkçe olmayan (iki dilli) 4-7 yaş çocuklarının dil düzeylerine etki eden faktörlerin incelenmesi. (Yayımlanmamış yüksek lisans tezi). Selçuk Üniversitesi, Sosyal Bilimler Enstitüsü, Konya.

Uyanık, Ö. (2010). Ankara örnekleminde Kaufman Erken Akademik ve Dil Becerileri Araştırma Testi'nin 61-72 aylık Türk çocuklarına uyarlanması. Yayımlanmamış yüksek lisans tezi. Gazi Üniversitesi, Eğitim Bilimleri Enstitüsü, Ankara.

Yazıcı, Z. (1999). Almanya ve Türkiye'de anaokuluna devam eden 60-76 aylar arasındaki Türk çocuklarının dil gelişimi ile okuma olgunluğu arasındaki ilişkinin incelenmesi.(Yayımlanmamış yüksek lisans tezi). Gazi Üniversitesi, Sosyal Bilimler Enstitüsü, Ankara.

Yazıcı, Z. (2003). íki dilli ve çok kültürlü ortamda yetişen çocuklar için anadilinin gerekliliği. Türk Dili, Dil ve Edebiyatı Dergisi, 622, $495-505$.

Yazııı, Z., andllter, B. (2008). Okul öncesi dönemdeki iki dilli/çok dilli çocukların dil kazanım süreci. Dil Araştırmaları Dergisi, 3, 47-61.

Yıldırım, A.(2008). Okul öncesi eğitim kurumlarından yararlanmayan 4-5 yaş çocuklarının dil gelişimini etkileyen faktörlerin incelenmesi (Konya ili örneği). (Yayımlanmamış yüksek lisans tezi). Selçuk Üniversitesi, Sosyal Bilimler Enstitüsü, Konya.

Yule, G. (2017). The study of language. Cambridge University Press. [Google Books versiyonu]. Erişim adresi: https://books.google.com.tr/books?hl=tr\&lr=\&id=jQIQDQAAQBAJ\&oi=fnd\&pg=PR10\&dq=The+study+of+language\&ots=GaWcKpsNGt\& sig=6n0k8HMHebmBmHY1pmlEZecGaCQ\&redir_esc=y\#v=onepage\& $q=T$ The\%20study\%20of\%20language \&f=false 